\title{
Successful treatment of cesarean scar pregnancy with transvaginal injection of absolute ethanol around the gestation sac via ultrasound
}

\author{
Fangfang Lu', Yuanming Liư ${ }^{2}$ and Wenjun Tang ${ }^{3^{*}}$ (D)
}

\begin{abstract}
Background: This study aims to evaluate the curative effect and complications in cesarean scar pregnancy (CSP) patients treated with a transvaginal injection of absolute ethanol (AE) around the gestation sac (GS) under ultrasound guidance.

Methods: This retrospective clinical investigation analyzed 26 CSP patients treated at the Affiliated Hospital of Guilin Medical University in Guilin, Guangxi, China, between January 1, 2018 and January 30, 2019. Outcomes and complications were analyzed following treatment with AE.

Results: Out of the entire group, 20 patients were successfully treated with a single AE injection, while the remaining six patients required two or three repeat injections. In 21 patients, the serum beta-human chorionic gonadotropin ( $\beta$-hCG) level was reduced to $>50 \% 1$ day after a single AE injection; in 19 patients, the serum $\beta$-hCG level was reduced to $>80 \%$ 4 days after a single AE injection. In all patients, the average time for serum $\beta$-hCG to reduce to normal levels $(<3.0 \mathrm{mIU} /$ $\mathrm{mL}$ ) was $36.50 \pm 12.54$ days. The overall cure rate of CSP by AE injection was $100 \%$. Average length of hospitalization was $6.73 \pm 3.66$ days, with Patient 2 having the longest hospitalization at 17 days, and Patient 3 the shortest at 2 days. No adverse effects on hematopoietic, hepatic or renal function were observed in the short term.

Conclusion: The study demonstrated that transvaginal injection of AE around the gestation sac under ultrasound guidance had good clinical effects, fewer complications, and merit as a novel treatment for CSP. However, larger multicenter trials are needed to confirm the safety and effectiveness of this treatment.
\end{abstract}

Keywords: Absolute ethanol, Cesarean scar pregnancy, Transvaginal ultrasonography

\section{Background}

In recent years, the cesarean section (CS) rate has increased globally. With this rise, the incidence of cesarean scar pregnancy (CSP) has also increased, particularly in China. The reported morbidity of CSP ranges from 1/ 2216 to $1 / 1800$ pregnancies, accounting for $4 \%$ of ectopic pregnancies $[1,2]$. CSP, a long-term complication of CS, is defined as the implantation of the gestational sac at the uterine incision scar of the previous CS. If treatment of CSP is delayed, it may lead to several

\footnotetext{
*Correspondence: tangwenjun56@qq.com

${ }^{3}$ Department of Clinical Laboratory, Affliated Hospital of Guilin Medical University, Guilin 541000, Guangxi, People's Republic of China Full list of author information is available at the end of the article
}

serious complications, including hemorrhage, uterine rupture, hysterectomy, and even loss of sequent fertility [3]. As such, standard management for CSP is timely termination of pregnancy.

Many treatments for CSP have been proposed. These include: uterine dilatation and curettage $(\mathrm{D} \& \mathrm{C})$, hysteroscopy, laparoscopy, resection of CSP through a transvaginal approach, uterine artery embolization (UAE), high-intensity focused ultrasound, treatment by potassium chloride, treatment by systemic methotrexate (MTX), treatment by local MTX, and combined medical and surgical management [4-10]. The efficacy and safety of these CSP therapies have been assessed in many research studies. One systematic review of CSP treatment indicated the efficacy rate of

(c) The Author(s). 2019 Open Access This article is distributed under the terms of the Creative Commons Attribution 4.0 International License (http://creativecommons.org/licenses/by/4.0/), which permits unrestricted use, distribution, and reproduction in any medium, provided you give appropriate credit to the original author(s) and the source, provide a link to the Creative Commons license, and indicate if changes were made. The Creative Commons Public Domain Dedication waiver (http://creativecommons.org/publicdomain/zero/1.0/) applies to the data made available in this article, unless otherwise stated. 
systemic and/or local MTX was $62 \%$, while surgical treatments were associated with a high success rate $(\geq 96 \%)$ and low risk of hemorrhage $(\leq 4 \%)$ [11]. Petersen et al. [10] systematically reviewed 2037 CSP patients and identified 14 different approaches, among which five were recommended for CSP treatment: transvaginal approach, hysteroscopy, laparoscopy, UAE in combination with $\mathrm{D} \& \mathrm{C}$, and UAE in combination with D\&C and hysteroscopy. Yamaguchi et al. [12] showed that transvaginal MTX injection cured eight CSP patients successfully. Another study reported the cure rate among 28 CSP patients at $100 \%$ via transvaginal ultrasound-guided embryo aspiration plus local MTX injection, an effective method with less complications or adverse effects [13]. However, the standard treatment protocol for CSP is not yet established.

Some data suggest absolute ethanol (AE) can also be used for ectopic pregnancy therapy. The first use of $\mathrm{AE}$ in the treatment of ectopic pregnancy was reported by Kaijima et al. [14] in 2006. Building on this study, Hisao et al. [15] recently reported a novel, less-invasive treatment for cervical pregnancy $(\mathrm{CP})$ and CSP using local $\mathrm{AE}$ injection, which may be superior to MTX-based local injection therapy. It was shown that injection of $\mathrm{AE}$ into the lacunar space around the gestation sac rapidly decreased serum beta-human chorionic gonadotropin ( $\beta$-hCG) [15]. The above research mainly studied the curative effect of $\mathrm{AE}$ injections on $\mathrm{CP}$ treatment. In our study, we focused on the treatment of CSP by transvaginal $\mathrm{AE}$ injection. The aim of the report was to evaluate the curative effect and complications among CSP patients treated with $\mathrm{AE}$.

\section{Methods}

Approved by the hospital's ethics committee, this retrospective clinical study analyzed 26 CSP patients treated at the Affiliated Hospital of Guilin Medical University in Guilin, Guangxi, China, between January 1, 2018 and January 30, 2019. Patient data were collected through archived medical records and all patients were clearly informed of their treatment modalities, as well as the risk of pregnancy preservation. All patients provided signed consent prior to the intervention. Clinical characteristics such as age, gravida para, size of gestation sac (GS), uterine scar thickness, and fetal heartbeat were reviewed. The change in serum $\beta$-hCG level and size of GS were dynamically measured after treatment. The change in white blood cells (WBC), hemoglobin ( $\mathrm{Hb})$, blood platelets (PLT), alanine transaminase (ALT), aspartate transaminase (AST), creatinine ( $\mathrm{Cr}$ ), and blood urea nitrogen (BUN) were also analyzed before and two months after treatment. Patients for whom follow-up was not possible were excluded from the study.

\section{Diagnostic criteria of CSP}

All patients became pregnant spontaneously. The diagnosis of CSP was based on standard sonographic $[16,17]$ findings, confirming the following: 1) No pregnancy sac in the uterine cavity or cervical canal; 2) The pregnancy sac was located in the scar of the previous cesarean section in the lower uterine segment; 3) Color doppler flow imaging showed high velocity and low obstruction of blood flow around the pregnancy sac; and 4) Continuity of the myometrium in the anterior uterine wall was interrupted, with the myometrium between the pregnancy sac and bladder wall thinner or even absent.

\section{Transvaginal injection of $\mathrm{AE}$ around the gestation sac} Administered without anesthesia, AE (Anhydrous Ethanol Injection; Xilong Scientific, Shantou, Guangdong, China) was injected in all patients around the GS using a 20-G puncture needle under guidance of high-intensity imaging transvaginal ultrasonography (TVU) (HD11XE, Philips, USA). In all patients, initial AE dose was between 4.0 and $15.0 \mathrm{~mL}$ (mean $8.38 \pm 2.65 \mathrm{~mL}$ ), depending on GS size and serum $\beta$-hCG level. When the GS was larger or level of serum $\beta$-hCG higher, the patient required a higher $\mathrm{AE}$ dose. Total AE dosage was between 4.0 and $30 \mathrm{~mL}$ (mean $11.15 \pm 6.37 \mathrm{~mL}$ ).

\section{Therapeutic evaluation}

All patients were hospitalized for treatment. The effect of $\mathrm{AE}$ local injection was evaluated based on percentage decrease of serum $\beta$-hCG, calculated by dividing the initial level of serum $\beta$-hCG before the first $\mathrm{AE}$ injection. A second $\mathrm{AE}$ dose was given if the initial level of serum $\beta$-hCG was higher than $65000 \mathrm{mIU} / \mathrm{mL}$, or the serum $\beta$-hCG decrease was $<50 \%$ one day after local injection, or $<80 \%$ four days after local injection and the patient needed to be reassessed in subsequent days. For patients whose decline in $\beta$-hCG levels were not satisfactory after the second injection, additional doses were administered until the required decline in $\beta$-hCG was achieved. The serum $\beta$-hCG level was rechecked on the first day and fourth day after AE injection, followed by one week after $\mathrm{AE}$ injection, two or three days after one week, and at one month until the required level was reached $(<3.0$ $\mathrm{mIU} / \mathrm{mL}$ ). Meanwhile, the size of the GS was dynamically measured by TVU after AE injection until it completely disappeared.

\section{Statistical analysis}

SPSS 13.0 statistical software (IBM Corp., Armonk, NY, USA) was used to process all data. Descriptive statistics are given as standard deviation of the mean, frequency, and percentage. Paired sample t-tests were employed to assess the change of WBC, $\mathrm{Hb}, \mathrm{PLT}, \mathrm{AST}, \mathrm{ALT}, \mathrm{Cr}$, and 
BUN before and after AE injections. A value of $P<0.05$ was defined as statistically significant.

\section{Results}

Table 1 shows the clinical features of the 26 CSP patients. Average patient age was $34.12 \pm 5.39$ years. Among the entire group, positive fetal heartbeat (FHB) was visible in 11 patients. In all patients, average uterine scar thickness was $4.07 \pm 2.07 \mathrm{~mm}$. A total of 20 patients were successfully treated with a single $\mathrm{AE}$ injection, with the remaining patients requiring two or three $\mathrm{AE}$ injections due to slowly decreasing serum $\beta$-hCG levels. Among the 26 patients, 18 received $4 \sim 10 \mathrm{~mL}$ of $\mathrm{AE}$ injection, five received 11 20 $\mathrm{mL}$ of $\mathrm{AE}$ injection, and three received $21 \sim 30 \mathrm{~mL}$ of $\mathrm{AE}$ injection. The overall cure rate of CSP by AE injection was $100 \%$.

In four patients $(2,14,15,19)$, the initial level of serum $\beta$-hCG was higher than $65000 \mathrm{mIU} / \mathrm{mL}$. Patients 2,14 , and 15 received second AE injections. Patient 19 received a third $\mathrm{AE}$ injection as the decline in $\beta$-hCG level was not obvious after the second injection $(<30 \%)$. In subsequent observation, all of them reached the required $\beta$-hCG level. In 21 CSP patients, serum $\beta$-hCG level was reduced $>50 \%$ one day after a single $\mathrm{AE}$ injection; this included Patients 2, 10 and 15, and Patient 13 who had the greatest decrease at $85.88 \%$. Patient 10 received repeated injections due to serum $\beta$-hCG level reduction $<80 \%$ four days after a single $\mathrm{AE}$ injection; subsequently, the $\beta$-hCG level gradually decreased to normal (patient 2 and 15 have shown above). In another five patients $(1,12,14,19,21)$, the decrease of serum $\beta$ hCG was $<50 \%$ and the smallest decline occurred in Patient 19 at $34.33 \%$. Patient 1 received third injections due to the decline in $\beta$-hCG level not being obvious after the second injection $(<30 \%)$ and finally decreased to an acceptable level. Patient 12 and 21 only received a single $\mathrm{AE}$ injection as their serum $\beta$-hCG level reduction was $>80 \% 4$ days after injection and the required $\beta$-hCG level was reached eventually (patients 14 and 19 as shown above). In 19 patients, the serum $\beta$-hCG level decreased $>80 \% 4$ days after a single AE injection, while decreased $<80 \%$ in the other seven patients $(1,2,10,14$, 15,19 and 23). Patient 23 only received a single $\mathrm{AE}$ injection due to serum $\beta$-hCG level reduction $>50 \% 1$ day after injection, then decreasing to an acceptable level (patients 1,2,10,14,15 and 19 has shown above). In all patients, average time for serum $\beta$-hCG to reach normal $(<3.0 \mathrm{mIU} / \mathrm{mL})$ was $36.50 \pm 12.54$ days. Average length of hospitalization was $6.73 \pm 3.66$ days. Patient 2 had the longest hospitalization at 17 days, while Patient 3 had the shortest at 2 days.

Decline of serum $\beta$-hCG levels in all CSP patients is shown in Fig. 1. In the of majority patients, time for serum $\beta$-hCG to drop to normal was 30 to 40 days.
Patients 14, 15, 19, and 20 required the longest time (60 days) and Patient 4 the shortest (9 days). Figure 2 shows the change of TVU after AE injections for patients 3, 5, 7 , and 11.

We further analyzed the change of WBC, Hb, PLT, ALT, $\mathrm{AST}, \mathrm{Cr}$, and BUN in all patients to evaluate short-term adverse effects of $\mathrm{AE}$ injection on hematopoietic function or hepatic and renal function. Table 2 shows values of $\mathrm{Hb}$, WBC, and PLT before AE injection were about $127.00 \pm$ $11.27 \mathrm{~g} / \mathrm{L}, 8.61 \pm 1.96 \times 10^{\wedge} 9 / \mathrm{L}$, and $264.88 \pm 58.80 \times 10^{\wedge} 9 / \mathrm{L}$, respectively. These values were not significantly different from those 2 months after $\mathrm{AE}$ injection $(P>0.05)$. Values of ALT and AST before AE injection were $15.33 \pm 10.38$ $\mathrm{U} / \mathrm{L}$ and $14.62 \pm 5.51 \mathrm{U} / \mathrm{L}$, respectively; the difference was not statistically significant compared with values at 2 months after $\mathrm{AE}$ injection $(P>0.05)$. Values of $\mathrm{Cr}$ and BUN were also similar before and 2 months after $\mathrm{AE}$ injections, as shown in Table $2(P>0.05)$. One patient (Patient 2) required symptomatic treatment for persistent bleeding $(>500 \mathrm{~mL})$ and a moderate hematoma $(\mathrm{Hb} 84 \mathrm{~g} / \mathrm{L})$.

\section{Discussion}

CSP is a rare type of ectopic pregnancy, which has increased in recent years due to a rise cesarean sections. As CSP may cause serious complications - including hemorrhage, uterine rupture, and hysterectomy - early diagnosis and timely treatment are critical. Affecting women of reproductive age, most patients tend to choose conservative treatment for pregnancy termination, desiring to preserve the uterus and retain reproductive function. In any case, the best treatment for CSP remains unclear.

Currently, many conservative strategies have been established, including systemic and/or local MTX, D\&C, hysteroscopy, laparoscopy, transvaginal resection, UAE, high-intensity focused ultrasound, and combined treatment [10, 18-21]. Among these, systemic and local MTX are the most widely used forms of management for CSP due to their minimally invasive nature [22]. MTX is a dihydrofolate reductase inhibitor used in the treatment of autoimmune diseases, malignancy, and as an abortifacient [1]. In CSP treatment, the mechanism of action of MTX is the inhibition of embryonic growth by causing the destruction of trophoblast cells and reducing local tissue blood flow, subsequently leading to embryonic death. Once trophoblast cells are destroyed, $\beta$-hCG is released into the blood, ultimately leading to an initial increase in serum $\beta$-hCG levels. Response to MTX occurs over 5 to 7 days [15]. Previous studies on MTX treatments provided conflicting results, likely due to differences in study design, definition of response, and additional treatment. Some researchers have confirmed the effectiveness of MTX and recommend it as the first choice for conservative treatment [12, 23]. Conversely, 


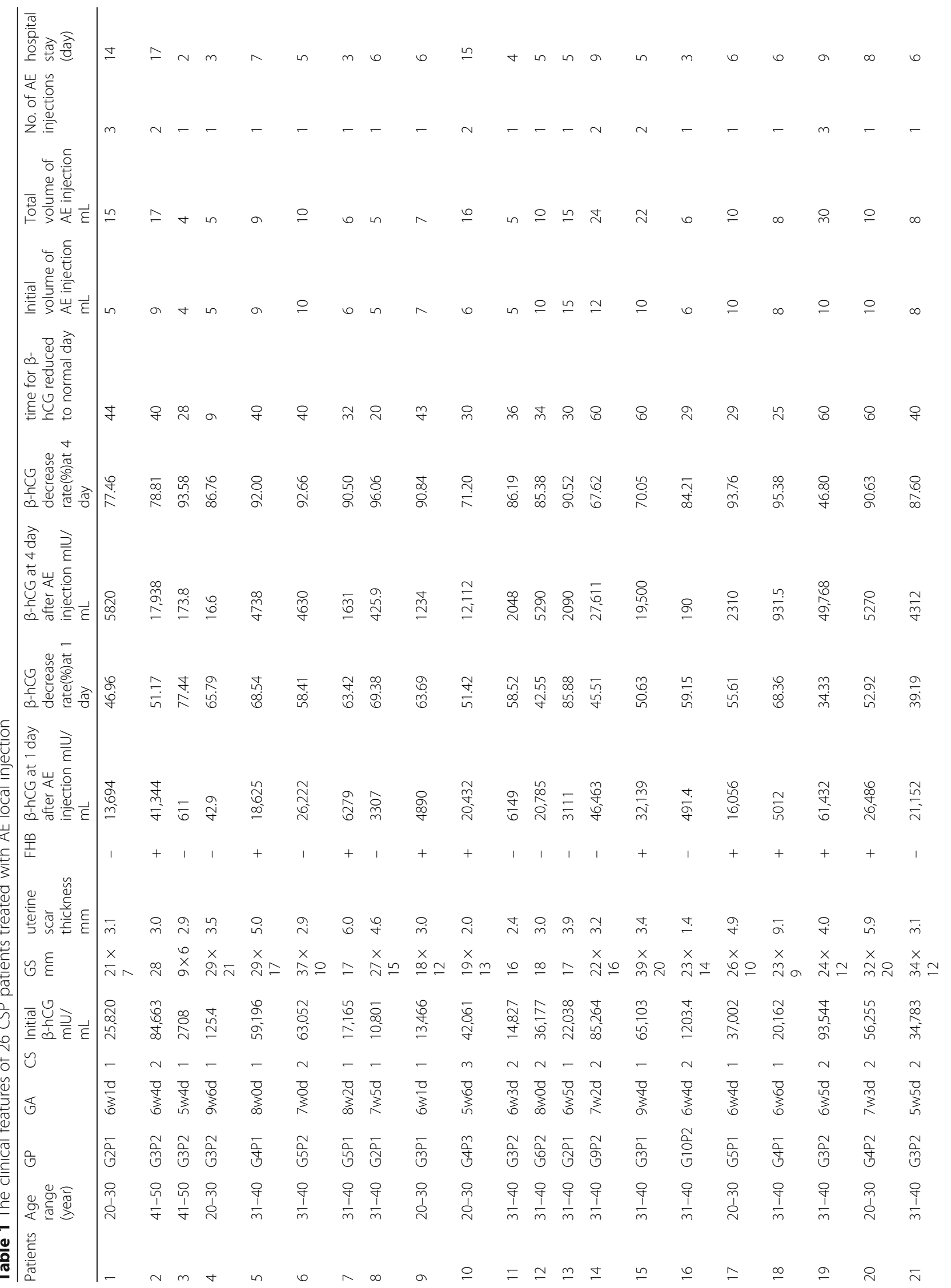




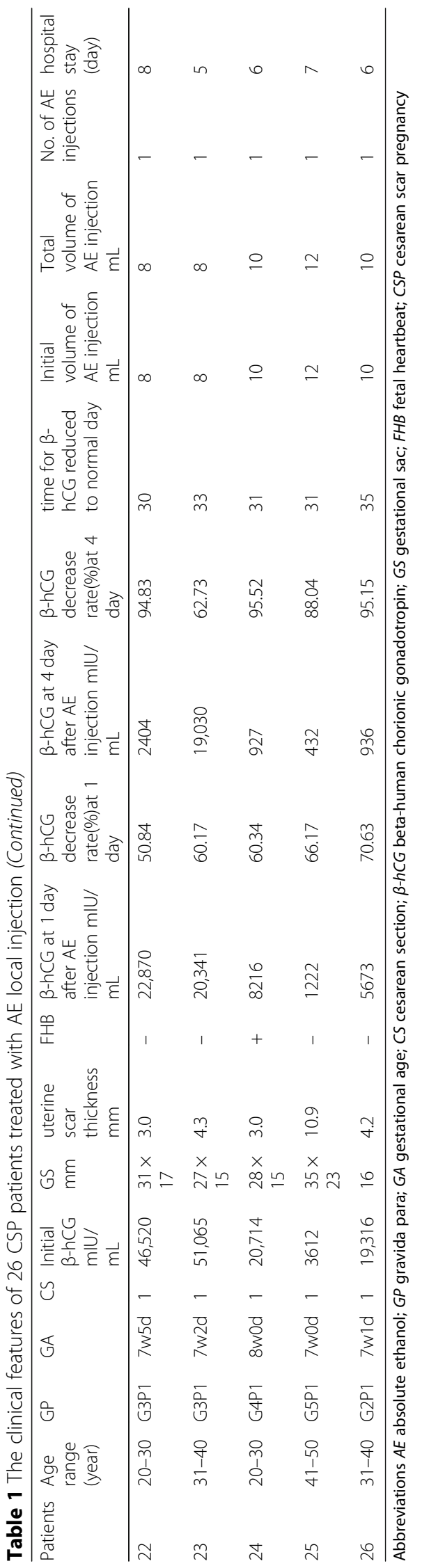




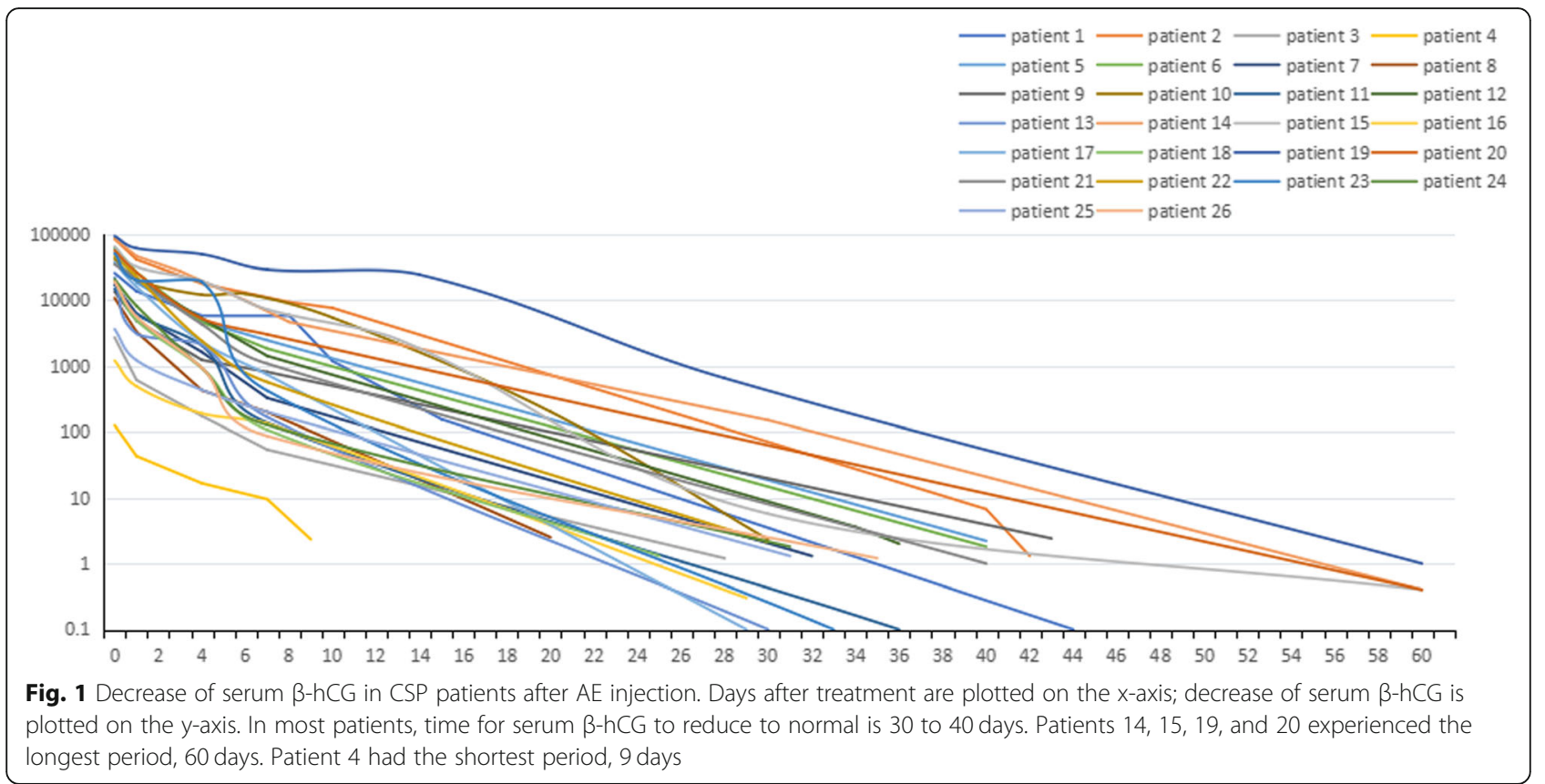

another review showed that nearly a quarter of patients treated with systemic MTX needed additional treatment, and severe complications occurred in $13 \%$ of cases [10]. Repeated use of MTX may result in genital infection, leukopenia, hepatic dysfunction, and vaginal bleeding [13]. For reproductive age women, MTX also showed embryo toxicity and teratogenicity. If treated with MTX, CSP patients require restrictive contraception for at least 3 months before a subsequent pregnancy. Therefore, it is necessary to explore more effective and less complicated CSP treatment methods.

As early as 1973, researchers reported the use of AE for the induction of mid-trimester abortions [24]. Subsequently, in 2006, AE injection was first used for ectopic pregnancy therapy [14]. Recently, Hisao et al. [15] reported usage of transvaginal $\mathrm{AE}$ injection for cervical pregnancy and CSP, known as "trophoblast target therapy" (TTT). They focused on 16 cervical pregnancy patients and 3 CSP patients, showing a successful outcome of TTT with $\mathrm{AE}$ injections. In our study, we used local injection of AE guided by transvaginal sonography to treat 26 CSP patients with gestational ages (GA) ranging from 5 weeks to 9 weeks and 6 days. We saw clinical success, with a curative rate of $100 \%$. Notably, 20 patients $(76.92 \%)$ underwent only one injection and attained a satisfactory result, while the remaining 6 patients $(23.08 \%)$ required repeat $\mathrm{AE}$ injections due to serum $\beta$-hCG levels decreasing slowly. In all patients, average time for serum $\beta$-hCG to reduce to normal $(<3.0 \mathrm{mIU} / \mathrm{mL})$ was $36.50 \pm 12.54$ days. The time for serum $\beta$-hCG levels to reduce to normal for the majority of patients ranged from 30 to 40 days. A few patients required 60 days, possibly related to high initial $\beta$-hCG levels or different sensitivity to $\mathrm{AE}$ treatment. This indicated that $\mathrm{AE}$ local injection around the gestation sac was effective for early pregnancy between 5 weeks to 9 weeks and 6 days, and also had an obvious effect on cases with positive FHB. However, it takes a long time for $\beta$-hCG to normalize. The mechanism of action for $\mathrm{AE}$ is causing trophoblastic necrosis through coagulation and dehydration, thus inhibiting proliferation of trophoblast cells, rapidly causing a reduction in serum $\beta$-hCG levels after initial injection. Furthermore, ethanol was metabolized quickly and did not accumulate in the body, making low-dose AE non-toxic, allowing for repeated injection as needed. Among 26 patients, $69.23 \%$ received $4 \sim 10 \mathrm{~mL}$ of $\mathrm{AE}$ injection, $19.23 \%$ received $11 \sim 20 \mathrm{~mL}$ of $\mathrm{AE}$ injection, and $11.54 \%$ received $21 \sim 30 \mathrm{~mL}$ of $\mathrm{AE}$ injection. Furthermore, we compared WBC, $\mathrm{Hb}, \mathrm{PLT}, \mathrm{AST}, \mathrm{ALT}, \mathrm{Cr}$, and BUN in all patients before and at 2 months after $\mathrm{AE}$ injections. Our results demonstrated that there were no significant differences in hematopoietic function, liver function, and renal function after treatment, indicating $\mathrm{AE}$ injection has no adverse effects on hematopoietic function or hepatic and renal function in the short term.

Massive hemorrhage is a common complication of CSP. In this study, only Patient 2 reported blood loss in excess of $500 \mathrm{~mL}$, subsequently requiring treatment. None of the patients experienced devastating hemorrhage. Uterine rupture is another serious complication. Li et al. [13] showed that the risk of uterine rupture is increased in patients having the gestational sac near the serous layer of the uterus. With expectant management, other researchers showed that the incidence of uterine rupture in CSP patients with embryonic/fetal heart activity was $9.9 \%$, 

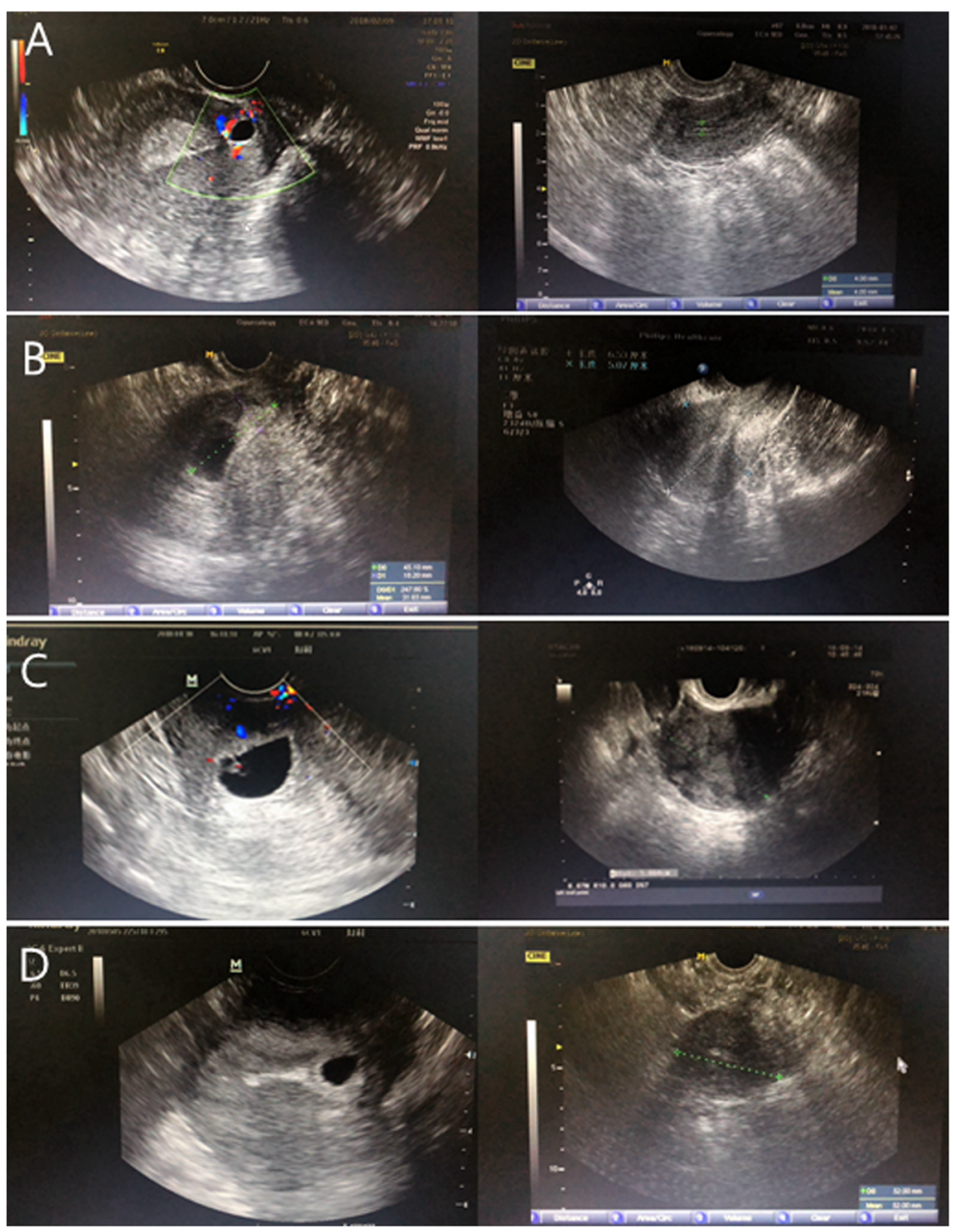

Fig. 2 Change in TVU after AE injection for patients 3, 5, 7, and 11(a) Change in TVU for Patient 3. b Change in TVU for Patient 5. c Change in TVU for Patient 7. $\mathbf{d}$ Change in TVU for Patient 11.

and hysterectomy was required in $15.2 \%$ during the first or second trimester, while uterine rupture rarely occurred in CSP patients without embryonic/fetal heart activity [25]. A recent review showed patients with multiple CS history and uterine scar thickness of $<2 \mathrm{~mm}$ were more

Table 2 Comparison of changes in routine blood index, liver function, and renal function before and after $A E$ injection

\begin{tabular}{llll}
\hline & \multicolumn{2}{c}{ Mean \pm SD } & $P$ value \\
\cline { 2 - 3 } & Before injection & Two month after injection & \\
\hline $\mathrm{Hb}(\mathrm{g} / \mathrm{L})$ & $127.00 \pm 11.27$ & $125.86 \pm 13.77$ & 0.626 \\
$\mathrm{WBC}\left(\times 10 \wedge^{9} / \mathrm{L}\right)$ & $8.61 \pm 1.96$ & $8.65 \pm 1.70$ & 0.901 \\
$\mathrm{PLT}\left(\times 10 \wedge^{9} / \mathrm{L}\right)$ & $264.88 \pm 58.80$ & $269.38 \pm 63.94$ & 0.603 \\
$\mathrm{ALT}(\mathrm{U} / \mathrm{L})$ & $15.33 \pm 10.38$ & $14.93 \pm 7.75$ & 0.774 \\
$\mathrm{AST}(\mathrm{U} / \mathrm{L})$ & $14.62 \pm 5.51$ & $15.30 \pm 5.85$ & 0.409 \\
$\mathrm{Cr}(\mathrm{umol} / \mathrm{L})$ & $52.51 \pm 8.44$ & $50.23 \pm 10.58$ & 0.144 \\
$\mathrm{BUN}(\mathrm{mmol} / \mathrm{L})$ & $4.21 \pm 1.80$ & $4.53 \pm 1.45$ & 0.063 \\
\hline
\end{tabular}

likely to suffer from complications [26]. In all 26 patients, average cesarean scar thickness was $4.07 \pm 2.07 \mathrm{~mm}$. Patient 25 had the thickest uterine scar $(10.90 \mathrm{~mm})$ and Patient 16 had the thinnest uterine scar $(1.40 \mathrm{~mm})$. No uterine rupture was observed in any patient. It is notable that preserving the uterus is a major concern for both patients and their physicians, as it may influence menstruation and future fertility plans. In our study, all patients were treated successfully by $\mathrm{AE}$ local injection and did not require hysterectomy after treatment, thereby preserving their reproductive ability. Despite serious complications of CSP, some patients choose to continue pregnancy as reported in some research [25, 27]. Timor et al. [25] showed that a significant proportion of CSP patients who declined pregnancy termination progressed to the third trimester; thus, they considered termination of pregnancy as not the only therapeutic option offered to these patients. However, $39.2 \%$ of patients had severe bleeding, while uterine rupture occurred in $10.2 \%$ of patients, with 
most of them diagnosed as having abnormally invasive placenta at delivery. Therefore, in clinical practice, CSP patients should be fully aware of the risks of continuing pregnancy, enabling them to make informed decisions regarding termination. However, without follow-up studies, we cannot draw conclusions about long-term complications and reproductive function.

This report had some weaknesses, including its retrospective nature, and small number of CSP cases, possibly leaving the results open to bias. Due to the absence of comparison with other CSP treatments, we cannot fully assess if $\mathrm{AE}$ local injection is superior to other conservative treatments. Another limitation is that all patients in our study were not assessed with long-term follow-up, so other potential complications of $\mathrm{AE}$ and its effect on fertility are unknown.

\section{Conclusions}

Transvaginal injection of $\mathrm{AE}$ around the gestation sac under the guidance of ultrasound showed good clinical effects and can be used as a novel treatment for CSP. CSP patients treated with AE local injections can attempt spontaneous pregnancy or in vitro fertilization and embryo transfer (IVF-ET) treatment without contraception. However, this retrospective clinical investigation involved a small sample size and may have some limitations. Future studies with larger multi-center trials are needed to confirm the safety and effectiveness of this treatment.

\section{Abbreviations}

AE: Absolute ethanol; ALT: Alanine transaminase; AST: Aspartate transaminase; BUN: Blood urea nitrogen; CP: Cervical pregnancy; Cr: Creatinine; CS: Cesarean sections; CSP: Cesarean scar pregnancy; D\&C: Dilation and curettage; FHB : Fetal heartbeat; GA: Gestational age; GP: Gravida para; Hb: Hemoglobin; MTX: Methotrexate; PLT: Blood platelets; TTT: Trophoblast target therapy; TVU: Transvaginal ultrasonography; UAE: Uterine artery embolization; WBC: White blood cells; $\beta$-hCG: Betahuman chorionic gonadotropin

\section{Acknowledgements}

None.

\section{Authors' contributions}

WJT contributed to the study design; FFL collected patients' information, performed statistical analysis and drafted the manuscript; YML collected patients' information. All authors have read and approved the manuscript.

\section{Funding}

None.

\section{Availability of data and materials}

We agree to allow the readers and journal to review our primary data if requested.

\section{Ethics approval and consent to participate}

The study was approved by the Ethics Committee of Affliated Hospital of Guilin Medical University. All patients provided signed consent prior to the intervention. All patients consented to analysis of their medical records in our manuscript and we obtained the permission from the hospital.

\section{Consent for publication}

We have obtained consent for the publication of identifying images or other personal or clinical details from 26 patients.

\section{Competing interests}

The authors declare that they have no competing interests.

\section{Author details}

${ }^{1}$ Department of Obstetrics and Gynecology, Affliated Hospital of Guilin Medical University, Guilin 541000, Guangxi, People's Republic of China. 2Department of Ultrasound, Affliated Hospital of Guilin Medical University, Guilin 541000, Guangxi, People's Republic of China. ${ }^{3}$ Department of Clinical Laboratory, Affliated Hospital of Guilin Medical University, Guilin 541000, Guangxi, People's Republic of China.

Received: 13 March 2019 Accepted: 20 August 2019

Published online: 27 August 2019

\section{References}

1. Rotas MA, Haberman S, Levgur M. Cesarean scar ectopic pregnancies: etiology, diagnosis, and management. Obstet Gynecol. 2006;107(6):1373-81.

2. Maymon R, Svirsky R, Smorgick N, et al. Fertility performance and obstetric outcomes among women with previous cesarean scar pregnancy. J Ultrasound Med. 2011:30(9):1179-84.

3. Qian ZD, Weng Y, Du YJ, et al. Management of persistent caesarean scar pregnancy after curettage treatment failure. BMC Pregnancy Childbirth. 2017;17(1):208.

4. Dior UP, Palma-Dias R, Reidy KL, et al. Cesarean scar pregnancies: incidence and factors associated with conversion to surgery from medical management. J Minim Invasive Gynecol. 2019;26(5):919-27.

5. Liu S, Sun J, Cai B, et al. Management of Cesarean Scar Pregnancy Using Ultrasound-Guided Dilation and Curettage. J Minim Invasive Gynecol. 2016; 23(5):707-11.

6. Zhuang YL, Huang LL. Uterine artery embolization compared with methotrexate for the management of pregnancy implanted within a cesarean scar. Am J Obstet Gynecol. 2009;201:152.e1-3.

7. Pirtea L, Balint $O$, Secosan $C$, et al. Laparoscopic resection of cesarean scar ectopic pregnancy after unsuccessful systemic methotrexate treatment. J Minim Invasive Gynecol. 2019;26(3):399-400.

8. Yang H, Li F, Zhang P, et al. Treatment of caesarean section scar pregnancy with systemic administration of methotrexate. Pak J Pharm Sci. 2018; 31(5(Special)):2287-90.

9. Czuczwar P, Stępniak A, Woźniak A, et al. Successful treatment of spontaneous heterotopic caesarean scar pregnancy by local potassium chloride injection with preservation of the intrauterine pregnancy. Ginekol Pol. 2016;87(10):727.

10. Birch Petersen K, Hoffmann E, Rifbjerg Larsen C, et al. Cesarean scar pregnancy: a systematic review of treatment studies. Fertil Steril. 2016; 105(4):958-67.

11. Maheux-Lacroix S, Li F, Bujold E, et al. Cesarean scar pregnancies: a systematic review of treatment options. J Minim Invasive Gynecol. 2017; 24(6):915-25.

12. Yamaguchi M, Honda R, Uchino K, et al. Transvaginal methotrexate injection for the treatment of cesarean scar pregnancy: efficacy and subsequent fecundity. J Minim Invasive Gynecol. 2014;21:877-83.

13. Li N, Zhu F, Fu S, et al. Transvaginal ultrasound-guided embryo aspiration plus local administration of low-dose methotrexate for caesarean scar pregnancy. Ultrasound Med Biol. 2012;38(2):209-13.

14. Kaijima $\mathrm{H}$, Osada $\mathrm{H}$, Kato $\mathrm{K}$, et al. The efficacy and safety of managing ectopic pregnancies with transvaginal ultrasound-guided local injections of absolute ethanol. J Assist Reprod Genet. 2006;23:293-8.

15. Osada H, Teramoto S, Kaijima HA, et al. Novel treatment for cervical and cesarean section scar pregnancies by transvaginal injection of absolute ethanol to trophoblasts: efficacy in 19 cases. J Minim Invasive Gynecol. 2019; 26(1):129-34.

16. Winder S, Reid S, Condous G. Ultrasound diagnosis of ectopic pregnancy [J]. Australas J Ultrasound Med. 2011;14:29-33.

17. Fylstra DL. Ectopic pregnancy within a cesarean scar: a review. Obstet Gynecol Surv. 2002;57:537-43.

18. Pędraszewski P, Wlaźlak E, Panek W, et al. Cesarean scar pregnancy -a new challenge for obstetricians. J Ultrason. 2018;18(72):56-62. 
19. Ohara Y, Wada S, Fukushi Y, et al. Laparoscopic Management of Cesarean Scar Pregnancy. J Minim Invasive Gynecol. 2019;26(5):798-9.

20. Grechukhina O, Deshmukh U, Fan L, et al. Cesarean scar pregnancy, incidence, and recurrence: five-year experience at a single tertiary care referral center [J]. Obstet Gynecol. 2018;132(5):1285-95.

21. Glenn TL, Bembry J, Findley AD, et al. Cesarean scar ectopic pregnancy: current management strategies. Obstet Gynecol Surv. 2018;73(5):293-302.

22. Uludag SZ, Kutuk MS, Ak M, et al. Comparison of systemic and local methotrexate treatments in cesarean scar pregnancies: time to change conventional treatment and follow-up protocols. Eur J Obstet Gynecol Reprod Biol. 2016;206:131-5.

23. Boza A, Boza B, Api M. Cesarean scar pregnancy managed with conservative treatment. Iran J Med Sci. 2016;41(5):450-5.

24. Gomel V, Carpenter CW. Induction of mid-trimester abortion with intrauterine alcohol. Obstet Gynecol. 1973:41:455-8.

25. Cali G, Timor-Tritsch IE, Palacios-Jaraquemada J, et al. Outcome of cesarean scar pregnancy managed expectantly:systematic review and meta-analysis [J]. Ultrasound Obstet Gynecol. 2018;51(2):169-75.

26. Giampaolino P, De Rosa N, Morra I, et al. Management of Cesarean Scar Pregnancy: A Single-Institution Retrospective Review. Biomed Res Int. 2018; 2018:6486407.

27. Timor-Tritsch IE, Khatib N, Monteagudo A, et al. Cesarean scar pregnancies: experience of 60 cases. J Ultrasound Med. 2015;34(4):601-10.

\section{Publisher's Note}

Springer Nature remains neutral with regard to jurisdictional claims in published maps and institutional affiliations.

Ready to submit your research? Choose BMC and benefit from:

- fast, convenient online submission

- thorough peer review by experienced researchers in your field

- rapid publication on acceptance

- support for research data, including large and complex data types

- gold Open Access which fosters wider collaboration and increased citations

- maximum visibility for your research: over $100 \mathrm{M}$ website views per year

At $\mathrm{BMC}$, research is always in progress.

Learn more biomedcentral.com/submissions 